\title{
The Local Economic Effects of Brexit
}

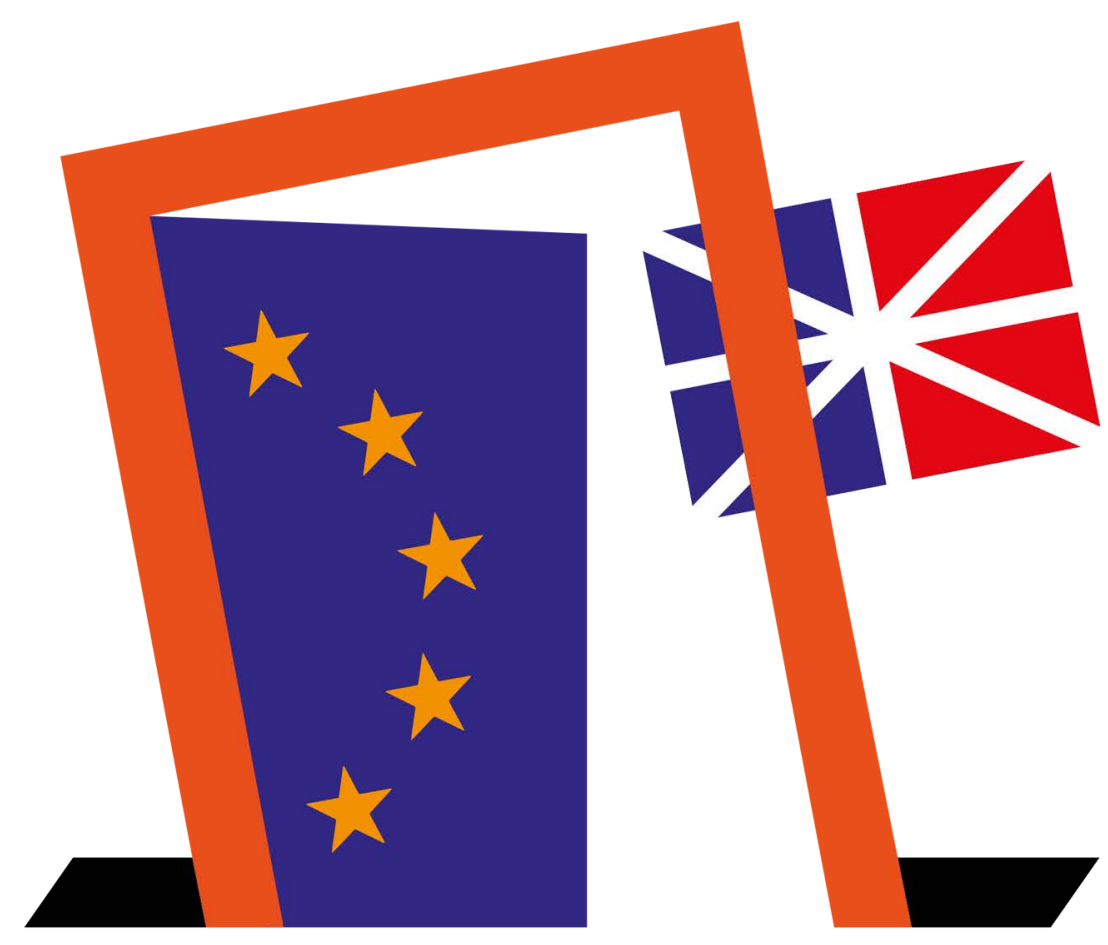




\section{CEP BREXIT ANALYSIS No.10}

\section{The Local Economic Effects of Brexit}

- This paper studies the local impacts of the increases in trade barriers associated with Brexit. Predictions of the local impact of Brexit are presented under two different scenarios, soft and hard Brexit.

- Average effects are predicted to be negative under both scenarios, and more negative under hard Brexit. The spatial variation in shocks across areas is somewhat higher under hard Brexit because some local areas are particularly specialised in sectors that are predicted to be badly hit by hard Brexit.

- Areas in the South of England, and urban areas, are predicted to be harder hit by Brexit under both scenarios. Again, this pattern is explained by the fact that those areas are specialised in sectors that are predicted to be badly hit by Brexit.

- Finally, the areas that were most likely to vote remain are those that are predicted to be most negatively impacted by Brexit. 


\section{Acknowledgements and disclaimer:}

Thanks to Rui Costa, Nikhil Datta, Hanwei Huang for excellent research assistance. Thanks to the Centre for Cities for help with the employment data and for providing the Local Authority and Primary Urban Area maps. The Centre for Economic Performance (CEP) is a politically independent Research Centre at the London School of Economics. The CEP has no institutional views, only those of its individual researchers. CEP's Brexit work is funded by the UK Economic and Social Research Council. As a whole the CEP, receives less than 5\% of its funding from the European Union. The EU funding is from the European Research Council for academic projects and not for general funding or consultancy. This work was part funded by an ESRC Brexit priority grant from UK in a Changing Europe. 


\section{Introduction}

In the run up to the UK-EU membership referendum in 2016 a number of studies examined the potential consequences of Brexit for the UK economy. Most mainstream studies, for example Dhingra et al. (2016a), HM Treasury (2016) and Kierzenkowski et al., (2016), predicted that Brexit would have a negative impact on UK GDP. Analysis by the Centre for Economic Performance, reported in Dhingra et al. (2016a) predicted annual costs of $£ 850$ per household with a 'soft-Brexit' and $£ 1,700$ per household with a 'hard Brexit'. Unsurprisingly these predicted effects are magnified in the long-run (to $£ 4,200$ and $£ 6,400$ respectively). In the soft Brexit scenario these results are driven by increases in non-tariff barriers and the exclusion of the UK from further EU market integration, while allowing for savings in the UK fiscal contribution to the EU. In the hard Brexit scenario, greater losses occur because of additional increases in non-tariff barriers, as well as the introduction of bilateral trade tariffs. ${ }^{1}$

The existing studies examine a number of additional impacts, including foreign investment (Dhingra et al., 2016b; HM Treasury, 2016; Kierzenkowski et al., 2016), immigration (Dhingra et al., 2016c; Ebell et al., 2016) and the distributional impacts across income groups (Breinlich et al. 2016). However, to the best of our knowledge, there exists no regional analysis of the welfare impacts of Brexit. This short paper provides such an analysis looking at the difference in predicted effects across all Local Authority Areas and, in an appendix, across Primary Urban Areas. It also provides some initial analysis on whether these predicted impacts are likely to exacerbate or alleviate existing disparities.

Predictions on the economic consequences of Brexit are of substantive interest for both central and local government in understanding how different areas might be affected by Brexit and in designing the appropriate policy response. There has also been considerable interest in how the predicted economic impacts of Brexit correlate with voting patterns from the referendum. ${ }^{2} \mathrm{We}$ provide some analysis that considers this correlation at the area level.

The analysis is based on predictions coming from the methodology applied in Dhingra et al. (2016a). Their multi sector computable general equilibrium trade model generates sectoral impacts under different scenarios (i.e. hard and soft Brexit). This state-of-the-art model of the world economy explains trade patterns well and accounts for the interdependence across sectors through complex supply chains. Using the most comprehensive data on trade flows and trade barriers available, their model provides estimates for the impact of different Brexit scenarios on trade volumes, sectoral production and real economic activity. ${ }^{3}$ Sectoral impacts can be weighted using area employment shares to estimate the overall area effect.

These comments notwithstanding, a number of important caveats apply to these results. It is important to note that the predicted sectoral impacts are model dependent and so we would urge considerable caution in placing strong weight on the estimated impact for any particular sector. To give just one example, the model focuses on international trade and will therefore underestimate losses in sectors, such as air transport, where foreign investment requirements are more important than trade barriers in determining market access.

\footnotetext{
${ }^{1}$ Precise definitions of these two scenarios are given in Appendix A1.

${ }^{2}$ See, for example, some of the contributions in Baldwin (2016) and Becker, Fetzer and Novy (2017).

${ }^{3}$ Dhingra et al. allow for multiple sectors and tradeable intermediate inputs and focus on the case of perfect competition which has been shown to provide a lower bound to the effects of changes in trade costs.
} 
It is possible to have more confidence in the area level results, where the employment share weighting will help 'wash-out' some of the sector-specific errors and hopefully give a more accurate prediction of the area level impacts of increased trade barriers. Even so, it must be emphasised that these area level results only predict the 'immediate impact' based on current employment shares. Just as with the financial crisis, there are good reasons to think that adjustment of the spatial economy, will have significant implications for understanding long run differences in the impact across areas. Future work will need to tackle these issues, but we believe that there is sufficient interest in understanding the immediate impact to warrant publication of these predictions.

The results show, as with the previous research, that the average area level effect is negative under both scenarios and more negative under hard Brexit. This is not surprising given that the same sectoral effects that underpinned predictions of the national impact are also used to predict the area level results. Of more interest is the fact that the variability of shocks at the Local Authority level is considerably higher under hard Brexit (the estimated standard deviation of spatial shocks being $0.19 \%$ for soft Brexit, $0.40 \%$ for hard Brexit). This suggests that some Local Authorities are particularly specialised in sectors that are predicted to be badly hit by hard Brexit. When looking at Primary Urban Areas average effects are more negative, consistent with the fact that urban areas have their employment concentrated in the sectors that are predicted to be most negatively affected. However, the variation under the two different scenarios is lower (with standard deviations of $0.17 \%$ for soft Brexit and $0.35 \%$ for hard Brexit) showing that sectoral diversification can help reduce negative impacts.

The interaction of area level sectoral employment shares with exposure of the relevant sectors determines the predicted losses for a particular area. Contrary to a small number of existing studies (see, e.g., Los et al. 2017), areas in London and the South East tend to see bigger negative impacts. We argue that this difference arises for two reasons. First, because studies based on measures of current trade exposure to the EU underestimate the importance of increases in non-tariff barriers (particularly in the hard Brexit scenario). Second, because simply looking at trade exposure ignores the willingness of individuals and firms to substitute away from foreign to domestic supply as trade-costs rise. The model in Dhingra et al. (2016a) accounts for both these factors.

Given these broad geographical patterns, we find that areas that were more likely to vote remain are those that are predicted to be most negatively impacted by Brexit. Finally, we also find that the negative impacts of Brexit tend to be bigger for areas with higher average wages. In our discussion, we highlight the parallel with the financial crisis, and specifically the contrast between the immediate and long run impacts (which saw London and the South East hit hardest before recovering much more strongly than other areas of the UK). This suggests that even though the immediate negative impacts are smaller in poorer regions, households in those areas start off poorer and may experience considerably more difficulty in adjusting to those negative shocks.

\section{Methodology and Data}

\section{Methodology}

The underlying methodology for predicting the sectoral impact of Brexit is described in Dhingra et al. (2016a). They estimate the effect of Brexit on the UK's trade and living standards 
using a modern quantitative trade model of the global economy. Quantitative trade models incorporate the channels through which trade affects consumers, firms and workers, and provide a mapping from trade data to welfare. The model provides predictions for how much real incomes change under different trade policies, using readily available data on trade volumes and potential trade barriers. Readers are referred to Dhingra et al. (2016a) for details.

The approach incorporates a broad class of models which make different assumptions about how goods are produced and how firms compete. It builds on Costinot and Rodríguez-Clare (2013) who show that some of the most popular trade models predict the same welfare changes in response to changing trade barriers and that these welfare changes can be computed using data on trade volumes and trade elasticities. ${ }^{4}$ Specifically, three pieces of information are used to predict the impact of the change in trade-costs associated with Brexit: the initial expenditure shares in each country on each sector, the income levels of different countries and the trade elasticity (which measures the percentage change in imports relative to domestic demand resulting from a one percent change in bilateral trade costs, holding incomes constant). ${ }^{5}$ The first two of these can be taken from existing data sets, while estimates of the trade elasticity are available from existing research.

Under the soft Brexit scenario Dhingra et al. (2016a) assume tariffs remain at zero and nontariff barriers increase. Tariffs remaining at zero would happen if the UK joins a free trade area, such as EFTA, with the EU. Non-tariff barriers are the costs arising from customs checks, border controls, differences in product market regulations, legal barriers and other transactions costs that make cross-border business more difficult. Even free trade areas cannot eliminate all the non-tariff barriers that businesses face when transacting across borders. Many non-tariff barriers arise because countries have different preferences over the regulations that they want to impose. As a result, trade deals can only reduce that fraction of the non-tariff barriers which can in principle be eliminated by policy action (so called 'reducible' non-tariff barriers). Berden et al. $(2009,2013)$ provide detailed calculations of the tariff equivalents of non-tariff barriers. Under the soft Brexit scenario, Dhingra et al. (2016a) assume that non-tariff barriers increase: they go up to one quarter of the reducible barriers faced by US exporters to the EU (a $2.77 \%$ increase). Given the way in which bilateral trade costs are modelled this increase in nontariff barriers (combined with the assumption of no changes in tariff barriers) translates in to a $2.77 \%$ increase in bilateral trade costs between the UK and the EU. ${ }^{6}$

Under the hard Brexit scenario, the UK and the EU are not part of a free trade agreement (at least immediately) and so they must charge each other the tariffs that they charge to other members of the World Trade Organization. This means that goods crossing the UK-EU border are faced with WTO Most-Favoured-Nation tariffs. Dhingra et al. (2016a) also assume that non-tariff barriers will be larger in the absence of a free trade agreement. Specifically, they are assumed to increase to three quarters of the reducible barriers faced by US exporters to the EU (an $8.31 \%$ increase). $^{7}$

\footnotetext{
${ }^{4}$ The paper is available at https://economics.mit.edu/files/9960.

${ }^{5}$ For example, the Chemicals and Chemical Products sector has a trade elasticity of 4.75 . This means a $10 \%$ increase in tariff in this sector between two countries would translate into a $0.475 \%$ reduction in the value of bilateral trade, holding fixed all economy-wide outcomes across countries.

${ }^{6}$ The model assumes frictional barriers of the iceberg type - i.e. Country $i$ has to ship $\tau_{\mathrm{ij}} \geq 1$ units of its good for one unit to reach country $\mathrm{j}$. Denoting (MFN) tariffs by $\mathrm{t}_{\mathrm{ij}}$ the effect of increasing tariffs and frictional barriers is to increase import prices at destination, which are given by $\mathrm{P}_{\mathrm{ij}}=\left(1+\mathrm{t}_{\mathrm{ij}}\right) \tau_{\mathrm{ij}} \mathrm{P}_{\mathrm{ii}}$.

${ }^{7}$ See footnote 6 for an explanation of how trade costs are modelled.
} 
With the change in bilateral trade costs specified, the model provides a way of simultaneously estimating the impact on bilateral trade volumes for each sector, taking into account all intersectoral linkages through supply chains and all inter-country linkages through diversion of trade to other countries. As there are multiple sectors, the model accounts for how changes in trade costs in intermediate input sectors affect the bilateral trade volumes of the final goods sector. As there are more than two countries, the model also accounts for how a rise in bilateral trade costs with one trade partner (in this case the EU) could also lead to a rise in bilateral trade for countries for whom the trade costs have not changed (i.e. among countries outside the EU). The trade model provides a logical aggregation of these different interlinkages across sectors and countries, which gives a set of predictions about what will happen to specific industries in the two different Brexit scenarios. To get the area level predictions, we simply multiple these predicted industry specific changes by the employment share of the industry in an area and sum across industries. ${ }^{8}$

\section{Data}

The national level trade flows and tariff data for each sector-country pair are taken from UN Comtrade $^{9}$ and the inter-industry linkages are taken from the World Input-Output Database. ${ }^{10}$ The latter data set can be used to calculate the initial expenditure shares in each country on each sector and the income levels of different countries. The trade elasticities that are used to translate the changes in trade-costs into effects on economic activity are taken from Caliendo and Parro (2015). As their estimated trade elasticity for the coke, refined petroleum and nuclear fuel sector is the highest, we re-estimate the sectoral effects in Dhingra et al. (2016a) setting the changes in this sector to zero. Our results therefore focus on the non-oil sector of the UK economy. ${ }^{11}$

The hard Brexit scenario uses Most Favoured Nation (MFN) tariffs at the WIOD sector level for both UK and EU imports and exports. These are calculated as weighted averages of the MFN tariffs reported in the World Trade Organisation (WTO) Statistics database, ${ }^{12}$ with weights taken from the WIOD and UN Comtrade databases.

Employment shares are calculated based on data from the Business Register and Employment Survey (BRES) mapped from 2007 SIC 5-digit level to SIC 2003 and then aggregated to the 31 WIOD industries. Employment shares are calculated based on reported data in 2015 so as to avoid possible employment decisions undertaken by firms as adjustment to the EU Referendum result of June 2016.

\footnotetext{
${ }^{8}$ Formally, the area level shock is calculated as: Shock $_{\mathrm{r}}=\sum_{i}^{N}$ Employment Share $_{\mathrm{ir}} \times$ National Shock $_{\mathrm{i}}$, where i stands for industry $(i=1,2, \ldots . . N)$ and $r$ stands for Local Authority $r$.

${ }^{9}$ See https://comtrade.un.org/.

${ }^{10}$ See Timmer et al. (2015) for details.

${ }^{11}$ The trade elasticities are sectoral specific for goods sectors, but the same for all service sectors (set equal to 5).

${ }^{12}$ http://stat.wto.org/Home/WSDBHome.aspx.
} 


\section{Results}

\section{Sector Predictions}

As per Dhingra et al. (2016a) under both hard and soft Brexit the estimated shocks to imports, exports and Gross Value Added (GVA) by WIOD sector are predominantly negative. The GVA impacts under the two different scenarios are reported in Table 1. The Table also shows that industry specific GVA shocks are on average lower under soft Brexit than under hard Brexit (the same is true for imports and exports). There is some heterogeneity in the responses of different sectors across the two different scenarios, however for each sector the sign of the impact - positive or negative - is generally consistent.

As discussed in the introduction, we would urge considerable caution in placing strong weight on the estimated impact for any particular sector. We have more confidence in the area level results where the employment share weighting will help 'wash-out' some of the sector-specific prediction errors and it is to these that we now turn.

Table 1: Sector Specific Impacts (\% change in GVA)

\begin{tabular}{|c|c|c|c|}
\hline ID & WIOD Industry & Soft Brexit (\%) & Hard Brexit (\%) \\
\hline 1 & Agriculture, Hunting, Forestry and Fishing & 3.3 & 4.2 \\
\hline 2 & Mining and Quarrying & -7.3 & -12.5 \\
\hline 3 & Food, Beverages and Tobacco & 1.4 & 2.8 \\
\hline 4 & Textiles and Textile Products; Leather, Leather and Footwear & -6.8 & -5.2 \\
\hline 5 & Wood and Products of Wood and Cork & 9.9 & 15.9 \\
\hline 6 & Pulp, Paper, Paper, Printing and Publishing & 3.5 & 6.3 \\
\hline 7 & Coke, Refined Petroleum and Nuclear Fuel & -0.5 & -0.8 \\
\hline 8 & Chemicals and Chemical Products & -8.9 & -15.1 \\
\hline 9 & Rubber and Plastics & -0.4 & -0.7 \\
\hline 10 & Other Non-Metallic Mineral & 0.2 & 0.2 \\
\hline 11 & Basic Metals and Fabricated Metal & 0.5 & 5.1 \\
\hline 12 & Machinery, nec & -0.1 & -0.2 \\
\hline 13 & Electrical and Optical Equipment & -9.5 & -6.3 \\
\hline 14 & Transport Equipment & -0.5 & -0.9 \\
\hline 15 & Manufacturing, nec; Recycling & 0.9 & 2.5 \\
\hline 16 & Electricity, Gas and Water Supply & -1.1 & -2.1 \\
\hline 17 & Construction & -1.4 & -2.6 \\
\hline \multirow[t]{2}{*}{18} & Retail Sale of Fuel; Wholesale Trade, Commission Trade, including & & \\
\hline & Motor Vehicles \& Motorcycles & -0.8 & -1.6 \\
\hline \multirow[t]{2}{*}{19} & Retail Trade, Except of Motor Vehicles \& Motorcycles; Repair of & & \\
\hline & Household Goods & -1.2 & -2.3 \\
\hline 20 & Hotels and Restaurants & 0.0 & -0.2 \\
\hline 21 & Inland Transport & -0.6 & -1.2 \\
\hline 22 & Water Transport & 4.7 & 9.1 \\
\hline 23 & Air Transport & 5.2 & 10.4 \\
\hline \multirow[t]{2}{*}{24} & Other Supporting and Auxiliary Transport Activities; Activities of & & \\
\hline & Travel Agencies & -1.3 & -2.5 \\
\hline 25 & Post and Telecommunications & -1.8 & -3.9 \\
\hline 26 & Financial Intermediation & -2.8 & -6.2 \\
\hline 27 & Real Estate Activities & -1.4 & -2.6 \\
\hline 28 & Renting of M\&Eq and Other Business Activities & -1.7 & -4.0 \\
\hline 29 & Education & -1.2 & -2.2 \\
\hline 30 & Health and Social Work & -1.3 & -2.4 \\
\hline 31 & Public Admin, Defence, Soc. Security \& other Public Svc & -1.1 & -2.3 \\
\hline
\end{tabular}




\section{Impact across Local Authority Areas}

Basic summary statistics for the impacts across Local Authorities are reported in Table 2. In line with the national estimates, the average Local Authority level effect is negative under both scenarios, and more negative under hard Brexit. As discussed above, this is not particularly surprising given that the same sectoral effects that underpinned predictions of the national impact are also used to predict the Local Authority level results. The average Local Authority decrease in GVA is predicted to be 1 percentage point larger under hard Brexit than under soft Brexit $(-2.12 \%$ compared to $-1.14 \%$, respectively). These figures are essentially unchanged if we use the median instead of the mean, suggesting that there are no particularly extreme predictions that drive the average effect. The figures for the $10^{\text {th }}$ and $90^{\text {th }}$ percentile are also consistent with this interpretation.

Table 2 also reports the variance and $90^{\text {th }}$ to $10^{\text {th }}$ percentile difference to summarise the extent to which the negative effect of Brexit varies across Local Authorities under the two different scenarios. This highlights a more interesting finding: the variation in Local Authority level shocks is considerably higher under hard Brexit. This suggests that some Local Authority areas are particularly specialised in sectors that are badly hit by hard Brexit.

Table 2: Basic Summary Statistics for GVA Impacts of Brexit on Local Authorities

\begin{tabular}{lcc}
\hline & Soft Brexit (\%) & Hard Brexit (\%) \\
\hline & & \\
Mean & -1.14 & -2.12 \\
$50^{\text {th }}$ Percentile (Median) & -1.16 & -2.11 \\
$10^{\text {th }}$ Percentile & -1.34 & -2.57 \\
$90^{\text {th }}$ Percentile & -0.91 & -1.65 \\
Standard Deviation & 0.19 & 0.40 \\
$90^{\text {th }}-10^{\text {th }}$ Percentile Differential & 0.43 & 0.92 \\
& & \\
\hline
\end{tabular}

Although the variation in impact across Local Authorities is higher in the hard Brexit scenario, the correlation between the two scenarios is strong and positive (the correlation coefficient is 0.91). Figure 1, which plots Local Authority impacts under both hard and soft Brexit illustrates this clearly. 
Figure 1: Impact of Brexit under Two Different Scenarios

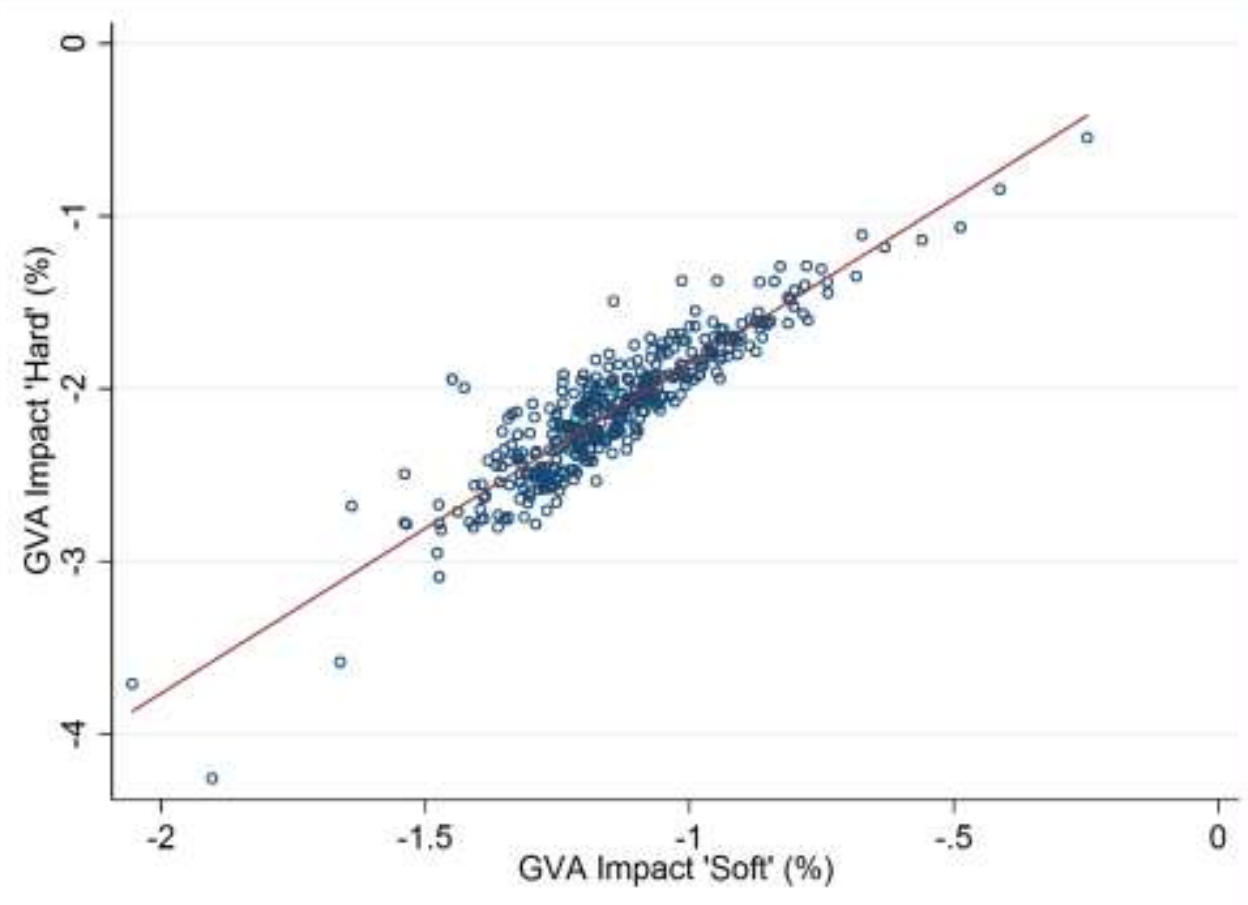

\section{Impact on Specific Local Authorities}

We now turn to the impact on specific Local Authorities. Table 3 provides a list of the top ten most and least affected Local Authorities under the hard Brexit scenario. The results for all Local Authorities are provided in Table A1 in Appendix A2. Three of the most negatively affected Local Authorities are within the Greater London area (City of London, Tower Hamlets and Islington). With the exception of Aberdeen, all the most negatively affected Local Authorities are in the South of England. Most of these areas have high employment shares in Business Activities or Financial Intermediation (or both) and so are particularly badly hit by the large negative effects predicted for those sectors under hard Brexit. For example, the City of London, which is predicted to see the largest decrease in GVA under a hard Brexit $(-4.3 \%)$ had close to $80 \%$ of its employed population working in these two sectors as of 2015 . 
Table 3: Most and Least Affected Local Authorities (\% Change in Gross Value Added)

\begin{tabular}{|c|c|c|c|c|c|}
\hline Top 10 & $\begin{array}{c}\text { Soft Brexit } \\
(\%)\end{array}$ & $\begin{array}{c}\text { Hard } \\
\text { Brexit } \\
(\%) \\
\end{array}$ & Bottom 10 & $\begin{array}{c}\text { Soft Brexit } \\
(\%)\end{array}$ & $\begin{array}{c}\text { Hard } \\
\text { Brexit } \\
(\%) \\
\end{array}$ \\
\hline City of London & -1.9 & -4.3 & Eden & -0.7 & -1.3 \\
\hline Aberdeen City & -2.1 & -3.7 & Moray & -0.7 & -1.3 \\
\hline Tower Hamlets & -1.7 & -3.6 & $\begin{array}{l}\text { North } \\
\text { Lincolnshire }\end{array}$ & -0.8 & -1.3 \\
\hline Watford & -1.5 & -3.1 & Corby & -0.8 & -1.3 \\
\hline Mole Valley & -1.5 & -3.0 & Anglesey & -0.6 & -1.2 \\
\hline East Hertfordshire & -1.5 & -2.8 & South Holland & -0.6 & -1.1 \\
\hline Reading & -1.4 & -2.8 & Crawley & -0.7 & -1.1 \\
\hline $\begin{array}{l}\text { Reigate and } \\
\text { Banstead }\end{array}$ & -1.4 & -2.8 & Isles of Scilly & -0.5 & -1.1 \\
\hline Worthing & -1.5 & -2.8 & Melton & -0.4 & -0.8 \\
\hline Islington & -1.3 & -2.8 & Hounslow & -0.2 & -0.5 \\
\hline
\end{tabular}

The ten least negatively affected regions show somewhat more geographical variation, although it is striking that the South of England is now somewhat under-represented. Hounslow and Crawley do relatively well because their proximity to Heathrow and Gatwick means a high share of employment in the Air Transport Industry, which sees only small loses even under hard Brexit. ${ }^{13}$

\footnotetext{
${ }^{13}$ Remember however that the model focuses on international trade and, as noted in the introduction, will therefore underestimate losses in sectors, such as air transport, where foreign investment requirements are more important than trade barriers in determining market access.
} 


\section{Figure 2: Maps of Percentage Decreases in Local Authority GVA}
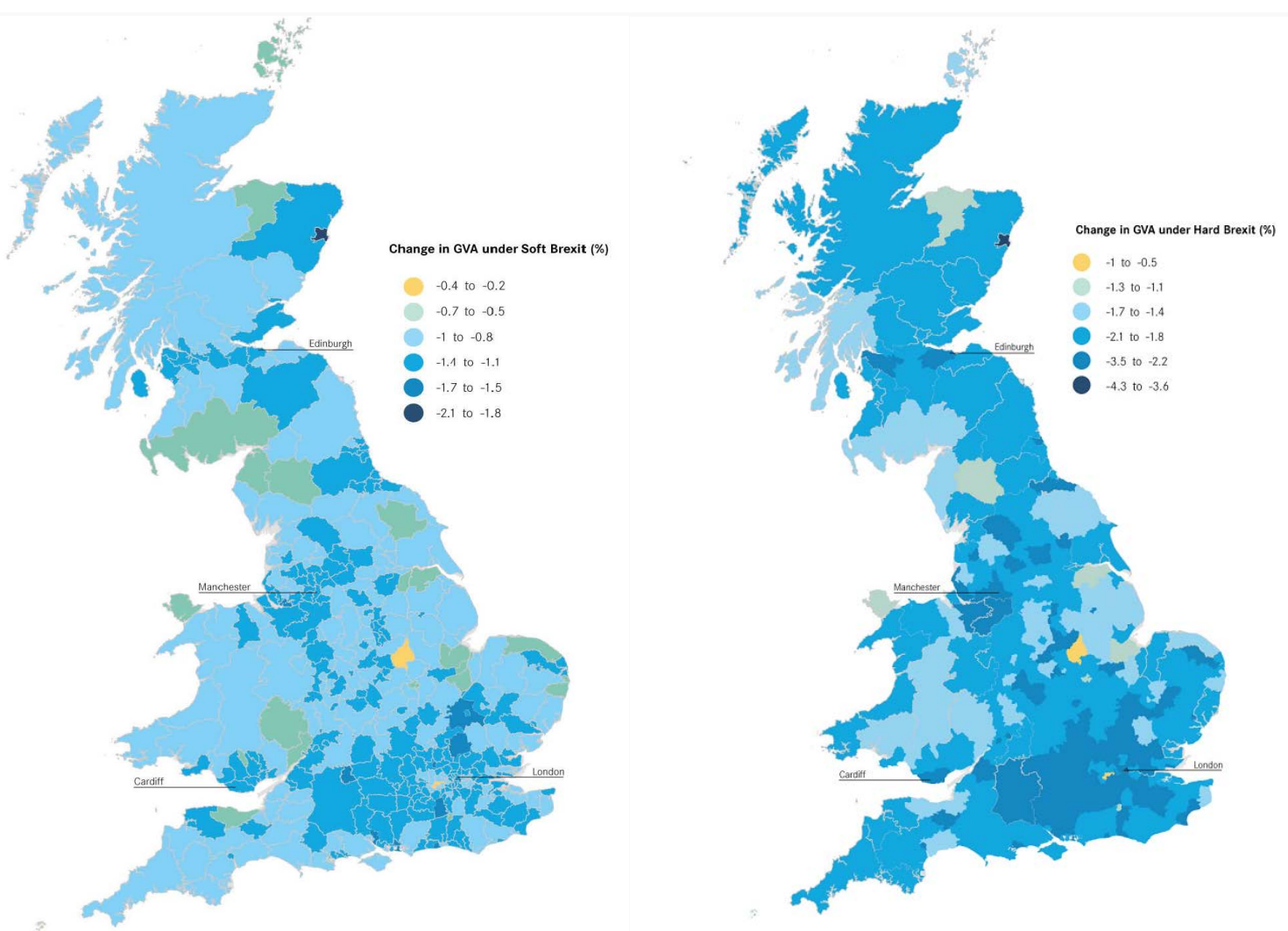

Figure 2 shows that these findings generalise when we look at the effect across all Local Authorities. The figure maps the percentage change in GVA by Local Authority under both soft and hard Brexit. The general geographical patterns are highly similar across both scenarios. A broad north south pattern is visible, especially in terms of the concentration of areas most negatively affected. The pattern for those less badly effected is more dispersed. The map also suggests that urban Local Authorities tend to be more negatively affected (consistent with their employment concentration in the most negatively affected sectors). Results for Primary Urban Areas, reported in Appendix A2, confirm that this is the case.

These overall patterns deviate markedly from a small number of existing studies (see, e.g., Los et al. 2017) which suggest that impacts are likely to be biggest outside of the South of England. Two factors would appear to explain these differences. First, existing studies are based on measures of trade exposure to the EU, which is larger for areas outside of the South of England. However, these measures of current exposure underestimate the importance of increases in non-tariff barriers (particularly in the hard Brexit scenario). Second, simply looking at trade exposure ignores the willingness of individuals and firms to substitute away from foreign to domestic supply as trade-costs rise. These substitution effects are largest in service industries that are concentrated in the South of England (and Primary Urban Areas). The model accounts for both these factors and thus predicts a strikingly different pattern in terms of those areas predicted to be most negatively affected by Brexit. 


\section{Correlations with Brexit Vote and Area Initial Conditions}

\section{Brexit Vote Correlations}

One obvious question arising from the overall patterns discussed above is how predicted impacts relate to vote shares in the referendum. Figure 3 provides an answer: areas that are predicted to be most negatively affected by Brexit were more likely to vote remain. The correlation is particularly striking for the predicted impacts under hard Brexit (correlation of 0.39 for hard Brexit as opposed to -0.24 for soft Brexit). Again, this finding differs from some existing studies because of the different geographical pattern for the places that are predicted to experience the most negative impacts from hard Brexit.

Figure 3: Brexit GVA Impact and Referendum Vote Share

(a): Soft Brexit

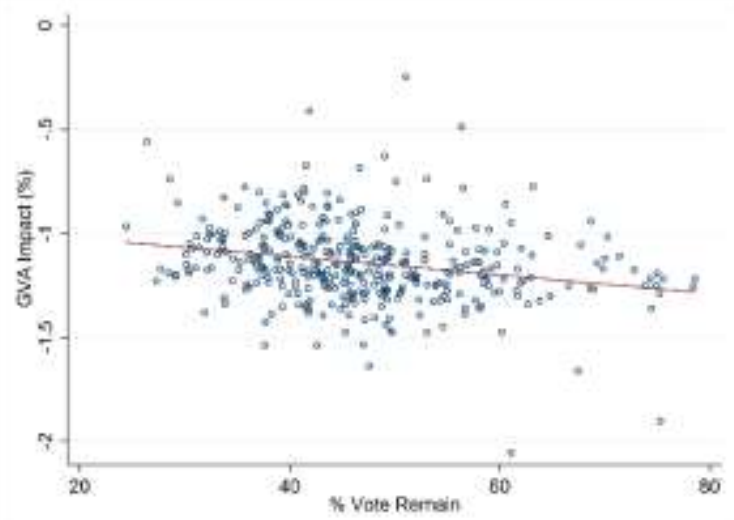

(b) Hard Brexit

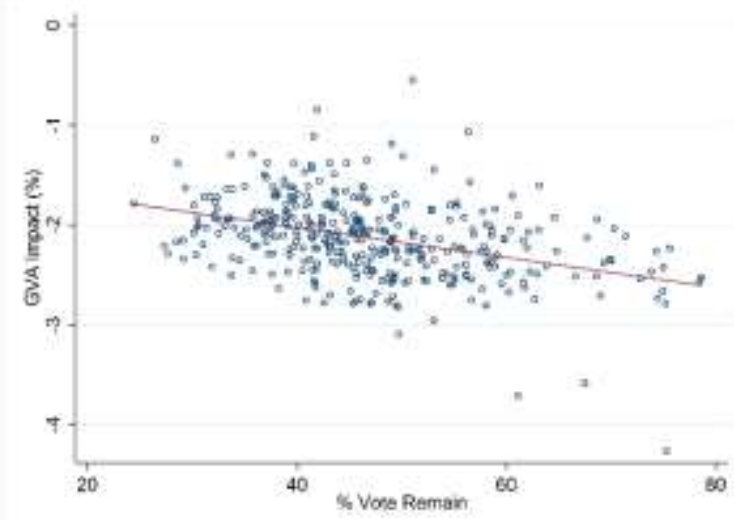

\section{Area Initial Conditions}

While the results so far imply a somewhat different narrative in terms of who is likely to lose most from Brexit, and how this relates to voting behaviour in the referendum, it is important to remember that the differences in expected impacts are swamped by existing disparities. Even though the immediate negative impacts are predicted to be smaller in poorer regions, households in those areas start off poorer and may experience considerably more difficulty in adjusting to those negative shocks. This is shown for the example of one initial condition, median wage levels, in Figure 4 (the correlation is -0.23 for soft Brexit, -0.37 for hard Brexit). 
Figure 4: Correlation of Brexit GVA Impact with Pre-Referendum Median Wage

(a): Soft Brexit

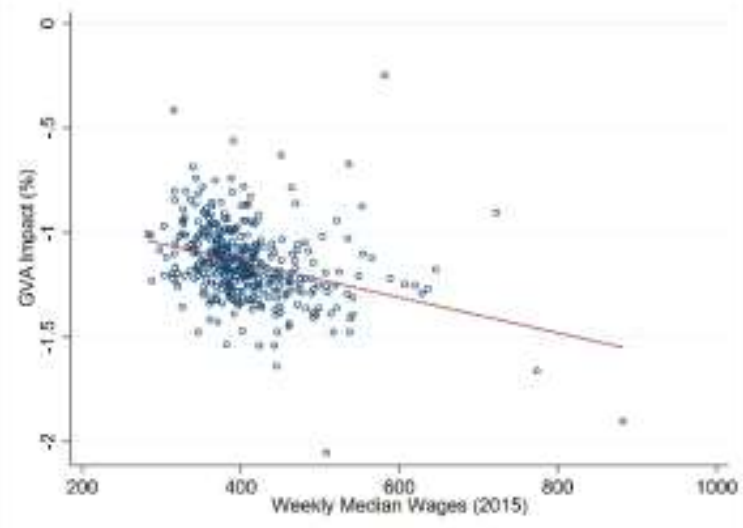

(b) Hard Brexit

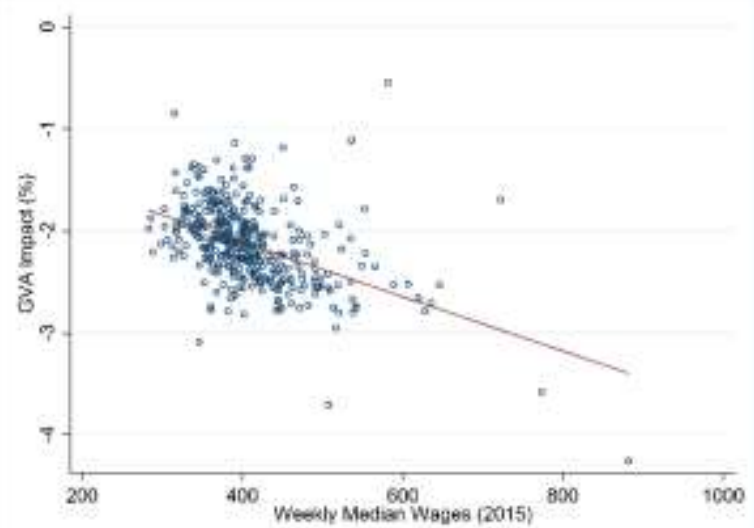

Finally, it is also important to note that the places experiencing the biggest initial shock are not necessarily those that will experience the most negative effects once the economy has adjusted. As discussed in the introduction, we would highlight the parallel with the financial crisis and specifically the contrast between the immediate and long run impacts (which saw London and the South East hit hardest before recovering much more strongly than other areas of the UK).

\section{Conclusions}

This paper has provided predictions of the impact of Brexit across Local Authorities under two different scenarios. Average effects are predicted to be negative under both scenarios and more negative under hard Brexit. The variation in shocks across Local Authorities is somewhat higher under hard Brexit because some Local Authorities are particularly specialised in sectors that are predicted to be badly hit by hard Brexit.

Local Authorities in the South of England, and those in urban areas, are predicted to be harder hit by Brexit under both scenarios. Again, this pattern is explained by the fact that those areas are specialised by sectors that are predicted to be badly hit by Brexit. We find that areas that were most likely to vote remain are those that are predicted to be most negatively impacted by Brexit. We also find that the negative impacts of Brexit tend to be bigger for areas with higher average wages.

The figures in this paper represent a first attempt to look at the Local Authority impacts of the increases in trade barriers associated with Brexit. Further work will be needed to better understand these impacts, to understand the impacts working through other channels, such as migration and investment, and to understand the longer run impacts as the economy adjusts. In short, these figures are far from the last word, but they do provide an initial indication of the way in which the impact of Brexit may be felt differently across the areas of Great Britain.

July 2017

\section{For further information, contact:}

Dr Swati Dhingra, Email: S.Dhingra@1se.ac.uk; Professor Stephen Machin, Email: s.j.machin@1se.ac.uk’; Professor Henry G. Overman, Email: h.g.overman@1se.ac.uk or Romesh Vaitilingam, Email: romesh@vaitilingam.com. 


\section{References}

Baldwin, R. (ed.) (2016) Brexit Beckons: Thinking Ahead by Leading Economists, Vox EU book.

Becker, S., T. Fetzer and D. Novy (2017) 'Who Voted for Brexit? A Comprehensive DistrictLevel Analysis', Centre for Economic Performance Discussion Paper No. 1480, April 2017.

Berden, K., J. Francois, S. Tamminen, M. Thelle and P. Wymenga (2009) 'Non-Tariff Measures in EU-US Trade and Investment - An Economic Analysis', Ecorys report prepared for the European Commission, Reference OJ 2007/S180219493.

Berden, K., J. Francois, K. Tamminen, M. Thelle and P. Wymenga (2013) 'Non-tariff Barriers in EU-US Trade and Investment: An Economic Analysis', Technical Report, Institute for International and Development Economics.

Breinlich, H. Dhingra, S., T. Sampson and J. Van Reenen (2016) 'Who Bears the Pain? How the Costs of Brexit Would be Distributed Across Income Groups', CEP BREXIT Paper No. 07.

Caliendo, L and F. Parro (2015) Estimates of the Trade and Welfare Effects of NAFTA. The Review of Economic Studies, 82 (1): 1-44

Costinot, A and A. Rodríguez-Clare (2013) Trade Theory with Numbers: Quantifying the Consequences of Globalization in Gopinath, G., E. Helpman and K. Rogoff (eds.) Handbook of International Economics, Elsevier. ISBN: 978-0-444-54314-1.

Dhingra, S., G. Ottaviano, T. Sampson and J. Van Reenen (2016a) 'The Consequences of Brexit for UK Trade and Living Standards’, CEP BREXIT Paper No. 02.

Dhingra, S., G. Ottaviano, T. Sampson and J. Van Reenen (2016b) 'The Impact of Brexit on Foreign Investment in the UK', CEP BREXIT Paper No. 03.

Dhingra, S., G. Ottaviano, J. Van Reenen and J. Wadsworth (2016c) 'Brexit and the Impact of Immigration on the UK', CEP BREXIT Paper No. 05.

Ebell, M. and J. Warren (2016) 'The Long-Term Economic Impact of Leaving the EU', National Institute Economic Review 236, 121-138.

Ebell M, I. Hurst and J. Warren (2016) 'Modelling the Long-run Economic Impact of Leaving the European Union', NIESR Discussion Paper No. 462.

HM Treasury (2016) 'The Long-Term Economic Impact of EU Membership and the Alternatives', ISBN 978-1-4741-3090-5.

Kierzenkowski, R., N. Pain, E. Rusticelli and S. Zwart (2016) 'The Economic Consequences of Brexit: A Taxing Decision', OECD Economic Policy Papers, No. 16, OECD Publishing, Paris. http://dx.doi.org/10.1787/5jm0lsvdkf6k-en 
Los, B., P. McCann, J. Springford and M. Thissen (2017) 'The Mismatch Between Local Voting and the Local Economic Consequences of Brexit'. Regional Studies 51(5).

Méjean, I. and C. Schwellnus (2009) 'Price convergence in the European Union: Within firms or composition of firms?' Journal of International Economics, 78(1), 1-10.

Timmer, M. P., Dietzenbacher, E., Los, B., Stehrer, R. and de Vries, G. J. (2015) 'An Illustrated User Guide to the World Input-Output Database: the Case of Global Automotive Production', Review of International Economics, 23: 575-605. 


\section{Appendices}

\section{Appendix A1: Hard and Soft Brexit and Timescales}

The soft Brexit scenario is defined by assuming that the UK remains in the Single Market and negotiates a deal like Norway with tariffs remaining at zero. However, non-tariff barriers are assumed to increase to one quarter of the reducible barriers faced by US exporters to the EU (a $2.77 \%$ increase). In addition, the UK will not fully benefit from further market integration of the EU. It is assumed that this further market integration reduces within EU non-tariff barriers $20 \%$ faster than for the rest of the world, which now includes the UK (this means within EU non-tariff barriers are $5.63 \%$ lower in 10 years). ${ }^{14}$ For the fiscal effect, we assume that UK could save $17 \%$ from its fiscal contribution to the EU (the same proportionate saving as Norway) - that is, approximately $0.09 \%$ of UK GDP.

Hard Brexit is defined by assuming that the UK and EU trade under World Trade Organization (WTO) conditions after Brexit. Non-tariff barriers increase to three quarters of the reducible barriers faced by US exporters to the EU (an $8.31 \%$ increase). Furthermore as before, the UK will not fully benefit from further integration of EU. It is assumed that these effects are larger outside of a free trade agreement and that this further integration reduces within EU non-tariff barriers $40 \%$ faster than in the rest of the world which now includes the UK (this means within EU barriers are $12.65 \%$ lower in 10 years). For the fiscal effect, we assume that the UK saves more on fiscal contributions to the EU than under Soft Brexit - specifically, $0.31 \%$ of UK GDP. For more details, see Dhingra et al. (2016a).

The assumption that it takes 10 years for the non-tariff barriers (NTB) within EU to converge to their new levels after Brexit means that the long run predictions reported in the paper correspond to the new equilibrium after 10 years of further EU integration.

\footnotetext{
${ }^{14}$ Mejean and Schwellnus (2009) provide evidence of faster market integration within the EU (based on faster observed price convergence).
} 


\section{Appendix A2: Full Results Table for Local Authorities}

Table A1 presents results for all Local Authorities under the two different scenarios.

Table A1: Impact of Brexit for Local Authorities (\% change Gross Value Added)

\begin{tabular}{|c|c|c|}
\hline Local Authority & $\begin{array}{c}\text { Soft Brexit } \\
(\%)\end{array}$ & $\begin{array}{c}\text { Hard Brexit } \\
\text { (\%) }\end{array}$ \\
\hline City of London & -1.9 & -4.3 \\
\hline Aberdeen City & -2.1 & -3.7 \\
\hline Tower Hamlets & -1.7 & -3.6 \\
\hline Watford & -1.5 & -3.1 \\
\hline Mole Valley & -1.5 & -3.0 \\
\hline East Hertfordshire & -1.5 & -2.8 \\
\hline Reading & -1.4 & -2.8 \\
\hline Reigate and Banstead & -1.4 & -2.8 \\
\hline Worthing & -1.5 & -2.8 \\
\hline Islington & -1.3 & -2.8 \\
\hline Swindon & -1.5 & -2.8 \\
\hline Halton & -1.5 & -2.8 \\
\hline Craven & -1.4 & -2.8 \\
\hline Three Rivers & -1.4 & -2.8 \\
\hline Slough & -1.4 & -2.8 \\
\hline Brentwood & -1.3 & -2.8 \\
\hline Wokingham & -1.4 & -2.8 \\
\hline St Albans & -1.3 & -2.7 \\
\hline Bracknell Forest & -1.3 & -2.7 \\
\hline Edinburgh, City of & -1.4 & -2.7 \\
\hline Hertsmere & -1.4 & -2.7 \\
\hline Westminster & -1.3 & -2.7 \\
\hline Salford & -1.4 & -2.7 \\
\hline Eastleigh & -1.6 & -2.7 \\
\hline South Cambridgeshire & -1.5 & -2.7 \\
\hline Bournemouth & -1.3 & -2.7 \\
\hline Camden & -1.3 & -2.7 \\
\hline Trafford & -1.3 & -2.6 \\
\hline Stockton-on-Tees & -1.4 & -2.6 \\
\hline Bristol, City of & -1.3 & -2.6 \\
\hline Rushmoor & -1.4 & -2.6 \\
\hline Harrow & -1.3 & -2.6 \\
\hline Tunbridge Wells & -1.2 & -2.6 \\
\hline Elmbridge & -1.3 & -2.6 \\
\hline Surrey Heath & -1.3 & -2.6 \\
\hline Leeds & -1.3 & -2.6 \\
\hline Ipswich & -1.3 & -2.6 \\
\hline Kingston upon Thames & -1.3 & -2.6 \\
\hline Hackney & -1.3 & -2.6 \\
\hline Nottingham & -1.3 & -2.6 \\
\hline
\end{tabular}


Basingstoke and Deane

Northampton

Bromley

Hart

Epsom and Ewell

Chiltern

Vale of White Horse

Milton Keynes

$-1.3$

Southwark

$-1.2$

$-2.5$

Windsor and Maidenhead

Cheshire West and Chester

Lambeth

Runnymede

Brighton and Hove

Glasgow City

South Oxfordshire

Woking

Broxbourne

Cardiff

Welwyn Hatfield

Guildford

Havant

Dacorum

Croydon

Merton

Cheshire East

Warrington

Redbridge

Manchester

$-1.2$

Barnet

$-1.2$

$-2.5$

Peterborough

Cambridge

South Gloucestershire

North Tyneside

Blaby

Dartford

Gloucester

Poole

Chelmsford

Wandsworth

Waverley

$-1.2$

Broxtowe

Exeter

$-1.2$

Harlow

Winchester

Stockport

$-1.4$

$-2.4$

$-1.3$

$-2.4$

$-1.3$

$-2.4$

Inverclyde

$-1.3$ 
Darlington

Fareham

Preston

Liverpool

$-2.4$

East Hampshire

$-2.4$

Richmond upon Thames

$-1.2$

$-2.4$

Bury

$-1.1$

$-2.4$

St Edmundsbury

$-1.3$

$-2.4$

Stevenage

$-1.3$

$-2.4$

Calderdale

$-1.3$

$-2.4$

Hammersmith and Fulham

$-1.3$

$-2.4$

Middlesbrough

$-1.1$

$-2.4$

West Lothian

$-1.2$

$-2.4$

Mid Sussex

$-1.3$

$-2.3$

Lewisham

$-1.2$

$-2.3$

West Berkshire

$-1.2$

$-2.3$

Maidstone

$-1.2$

$-2.3$

Warwick

$-1.2$

$-2.3$

Bolsover

$-1.2$

$-2.3$

Sefton

$-1.2$

$-2.3$

Taunton Deane

$-1.2$

$-2.3$

Birmingham

$-1.2$

$-2.3$

Redcar and Cleveland

$-1.2$

$-2.3$

Coventry

Sevenoaks

Wycombe

$-1.3$

$-2.3$

$-1.2$

$-2.3$

Broadland

$-1.2$

$-2.3$

North West Leicestershire

$-1.2$

$-2.3$

Test Valley

$-1.2$

$-2.3$

Sutton

$-1.3$

$-2.3$

Havering

Waltham Forest

$-1.2$

$-2.3$

$-1.1$

$-2.3$

Epping Forest

$-1.2$

$-2.3$

Norwich

$-1.2$

$-2.3$

Thurrock

$-1.2$

$-2.3$

Shepway

$-2.3$

Lincoln

Knowsley

Solihull

Tonbridge and Malling

$-1.2$

$-1.2$

$-2.3$

$-1.2$

North Hertfordshire

$-1.1$

$-2.3$

$-1.1$

$-2.3$

The Vale of Glamorgan

$-2.3$

East Renfrewshire

$-1.3$

$-2.3$

Wiltshire

$-1.2$

$-2.3$

York

Renfrewshire

Rushcliffe

Harrogate

Aylesbury Vale 


\begin{tabular}{|c|c|c|}
\hline Swansea & -1.2 & -2.3 \\
\hline Horsham & -1.2 & -2.2 \\
\hline Rossendale & -1.4 & -2.2 \\
\hline Wirral & -1.2 & -2.2 \\
\hline South Bucks & -1.1 & -2.2 \\
\hline Newham & -1.1 & -2.2 \\
\hline Enfield & -1.2 & -2.2 \\
\hline Bedford & -1.2 & -2.2 \\
\hline Portsmouth & -1.2 & -2.2 \\
\hline Haringey & -1.2 & -2.2 \\
\hline Greenwich & -1.1 & -2.2 \\
\hline West Dunbartonshire & -1.2 & -2.2 \\
\hline Bolton & -1.2 & -2.2 \\
\hline Newcastle upon Tyne & -1.1 & -2.2 \\
\hline Chorley & -1.2 & -2.2 \\
\hline Ashford & -1.2 & -2.2 \\
\hline Tandridge & -1.1 & -2.2 \\
\hline Spelthorne & -1.1 & -2.2 \\
\hline Rugby & -1.2 & -2.2 \\
\hline Aberdeenshire & -1.2 & -2.2 \\
\hline Bath and North East Somerset & -1.1 & -2.2 \\
\hline Castle Point & -1.2 & -2.2 \\
\hline Medway & -1.2 & -2.2 \\
\hline Thanet & -1.3 & -2.2 \\
\hline Doncaster & -1.2 & -2.2 \\
\hline Derby & -1.2 & -2.2 \\
\hline Bromsgrove & -1.1 & -2.2 \\
\hline Stafford & -1.3 & -2.2 \\
\hline Lancaster & -1.1 & -2.2 \\
\hline Gateshead & -1.2 & -2.2 \\
\hline Great Yarmouth & -1.2 & -2.2 \\
\hline Bexley & -1.1 & -2.2 \\
\hline Rochdale & -1.3 & -2.2 \\
\hline Canterbury & -1.1 & -2.2 \\
\hline East Cambridgeshire & -1.3 & -2.2 \\
\hline North Lanarkshire & -1.2 & -2.2 \\
\hline Mansfield & -1.2 & -2.2 \\
\hline Charnwood & -1.3 & -2.1 \\
\hline Eastbourne & -1.1 & -2.1 \\
\hline Newport & -1.2 & -2.1 \\
\hline Dundee City & -1.2 & -2.1 \\
\hline Bradford & -1.2 & -2.1 \\
\hline Lewes & -1.2 & -2.1 \\
\hline Sheffield & -1.2 & -2.1 \\
\hline West Oxfordshire & -1.3 & -2.1 \\
\hline Staffordshire Moorlands & -1.1 & -2.1 \\
\hline Rother & -1.1 & -2.1 \\
\hline Brent & -1.1 & -2.1 \\
\hline Stirling & -1.1 & -2.1 \\
\hline
\end{tabular}


Harborough

South Tyneside

Plymouth

Blackburn with Darwen

Daventry

Leicester

$-1.1$

East Dunbartonshire

$-1.2$

Fife

$-1.1$

Sunderland

$-1.2$

$-2.1$

Gravesham

$-1.2$

$-2.1$

Colchester

$-1.1$

North Ayrshire

$-1.1$

$-2.1$

Tewkesbury

$-1.2$

$-2.1$

Torbay

$-1.2$

$-2.1$

Denbighshire

$-1.1$

$-2.1$

Barking and Dagenham

$-1.3$

$-2.1$

Hastings

$-1.1$

$-2.1$

Tamworth

North Devon

$-1.2$

$-2.1$

North East Lincolnshire

$-1.2$

$-2.1$

Fylde

$-1.2$

$-2.1$

St. Helens

$-1.1$

$-2.1$

Mendip

$-1.0$

$-2.1$

Midlothian

Cotswold

Stratford-on-Avon

Central Bedfordshire

$-1.1$

$-2.1$

$-1.1$

$-2.1$

$-1.1$

$-2.1$

$-1.1$

$-2.1$

Chesterfield

$-1.1$

$-2.1$

Bridgend

$-1.2$

$-2.1$

South Norfolk

$-1.2$

$-2.1$

Newcastle-under-Lyme

$-1.1$

$-2.1$

Rhondda, Cynon, Taff

$-1.2$

$-2.1$

East Ayrshire

$-1.2$

$-2.1$

$-1.1$

$-2.1$

Adur

$-1.1$

$-2.1$

South Lanarkshire

$-1.1$

$-2.1$

Ealing

Suffolk Coastal

$-1.0$

$-2.0$

Falkirk

Southampton

North Somerset

South Staffordshire

$-1.1$

$-2.0$

$-1.1$

$-2.0$

$-1.0$

$-2.0$

$-1.1$

$-2.0$

$-1.2$

$-2.0$

Lichfield

$-1.1$

$-2.0$

Oxford

Worcester

$-1.0$

$-2.0$

Basildon

$-1.1$

$-2.0$

Kirklees

$-1.1$

$-2.0$

$-1.2$

$-2.0$

Wigan

$-1.1$

$-2.0$

Nuneaton and Bedworth

$-1.1$

$-2.0$

Hartlepool

$-1.2$

$-2.0$ 
Oldham

Scottish Borders

Arun

$-2.0$

North Warwickshire

$-2.0$

Wyre

$-2.0$

New Forest

$-2.0$

Stoke-on-Trent

$-2.0$

Cherwell

$-2.0$

County Durham

$-2.0$

South Ribble

$-2.0$

Redditch

Torfaen

$-2.0$

Teignbridge

$-2.0$

Gwynedd

$-2.0$

Weymouth and Portland

$-2.0$

Telford and Wrekin

$-2.0$

Luton

$-2.0$

Babergh

Christchurch

Wyre Forest

$-2.0$

$-2.0$

$-2.0$

East Dorset

Northumberland

$-2.0$

$-1.2$

$-2.0$

Mid Suffolk

$-1.1$

$-2.0$

South Northamptonshire

$-1.1$

$-2.0$

Huntingdonshire

Maldon

$-2.0$

$-1.1$

$-2.0$

Malvern Hills

$-1.1$

$-2.0$

Conwy

$-1.2$

$-1.9$

Stroud

$-1.1$

$-1.9$

$-1.0$

$-1.9$

Wellingborough

$-1.4$

$-1.9$

Kensington and Chelsea

$-1.1$

$-1.9$

Blackpool

$-0.9$

$-1.9$

Burnley

$-1.0$

$-1.9$

King`s Lynn and West Norfolk

$-1.1$

-1.9
-1.9

Rochford

$-1.0$

-1.9
-1.9

Braintree

$-1.0$

-1.9
-1.9

Walsall

$-1.1$

$-1.9$

Wakefield

Tendring

$-1.2$

$-1.9$

$-1.1$

$-1.9$

Isle of Wight

$-1.1$

$-1.9$

$-1.1$

$-1.9$

West Dorset

$-1.1$

$-1.9$

Highland

$-1.0$

$-1.9$

East Lothian

$-1.0$

$-1.9$

Caerphilly

Blaenau Gwent

$-1.2$

$-1.9$

Purbeck

$-1.2$

$-1.9$

$-1.0$

$-1.9$

East Riding of Yorkshire

$-1.0$

$-1.9$

Chichester

$-1.0$

$-1.9$

Breckland

$-1.0$

$-1.9$ 
Perth and Kinross

Swale

Rotherham

$-1.1$

$-1.9$

Wealden

$-1.0$

$-1.9$

East Staffordshire

$-1.0$

$-1.9$

Gedling

$-1.2$

$-1.9$

Torridge

$-1.0$

$-1.9$

Clackmannanshire

$-1.0$

$-1.9$

Wolverhampton

$-1.1$

$-1.9$

Tameside

$-1.1$

$-1.9$

Gosport

$-1.0$

$-1.9$

Rutland

$-1.1$

$-1.9$

South Hams

$-1.0$

$-1.9$

South Lakeland

$-1.1$

$-1.8$

South Ayrshire

$-1.0$

$-1.8$

Cornwall

$-0.9$

$-1.8$

Kingston upon Hull, City of

$-1.0$

$-1.8$

North Dorset

$-1.2$

$-1.8$

High Peak

$-1.1$

$-1.8$

Richmondshire

$-0.9$

$-1.8$

Eilean Siar

$-0.9$

$-1.8$

Carlisle

$-1.0$

$-1.8$

Selby

$-1.1$

$-1.8$

Ceredigion

$-0.9$

Ashfield

South Somerset

$-1.2$

$-1.8$

$-1.8$

Kettering

$-1.0$

$-1.8$

$-1.0$

$-1.8$

Monmouthshire

$-1.0$

$-1.8$

Pembrokeshire

$-1.0$

$-1.8$

Hillingdon

$-0.9$

$-1.8$

Boston

Angus

East Northamptonshire

$-1.0$

$-1.8$

$-1.1$

$-1.8$

$-1.0$

$-1.8$

Mid Devon

$-1.1$

$-1.8$

Shropshire

$-0.9$

$-1.8$

Bassetlaw

$-1.0$

$-1.8$

West Devon

$-0.9$

$-1.8$

Hinckley and Bosworth

Derbyshire Dales

$-1.1$

$-1.7$

East Devon

$-1.1$

$-1.7$

$-0.9$

$-1.7$

Dudley

Oadby and Wigston

$-1.0$

$-1.7$

$-1.0$

$-1.7$

Cannock Chase

$-1.0$

$-1.7$

Barrow-in-Furness

South Derbyshire

$-1.0$

$-1.7$

Barnsley

$-0.9$

$-1.7$

Wrexham

$-0.9$

$-1.7$

$-1.1$

$-1.7$

West Lindsey

$-0.9$

$-1.7$

Dover

$-0.9$

$-1.7$ 
Argyll and Bute

Carmarthenshire

Uttlesford

Copeland

South Kesteven

$-1.7$

Flintshire

$-1.7$

West Lancashire

$-1.7$

Scarborough

$-1.7$

Ribble Valley

$-1.7$

Hyndburn

$-1.6$

Sandwell

$-1.6$

East Lindsey

$-1.6$

Hambleton

$-1.6$

Newark and Sherwood

$-1.6$

West Somerset

$-1.6$

North Kesteven

$-1.6$

Powys

$-1.6$

North Norfolk

Forest Heath

Orkney Islands

$-1.6$

$-1.6$

Sedgemoor

$-1.6$

Shetland Islands

$-1.6$

Wychavon

$-1.6$

Erewash

$-1.6$

Waveney

$-1.6$

Pendle

Merthyr Tydfil

Herefordshire, County of

$-1.5$

$-1.5$

$-1.1$

$-1.5$

Dumfries and Galloway

$-0.8$

$-0.8$

$-1.5$

Forest of Dean

$-0.7$

$-1.4$

Allerdale

$-0.8$

$-1.4$

Amber Valley

$-0.8$

$-1.4$

Fenland

$-0.9$

$-1.4$

Ryedale

$-0.7$

$-1.4$

Neath Port Talbot

$-0.8$

$-1.4$

North East Derbyshire

$-1.0$

$-1.4$

$-0.9$

$-1.4$

Eden

$-0.7$

$-1.3$

Moray

$-0.7$

$-1.3$

North Lincolnshire

$-0.8$

$-1.3$

Corby

$-0.8$

$-1.3$

Anglesey

$-0.6$

$-1.2$

South Holland

$-0.6$

$-1.1$

Crawley

$-0.7$

$-1.1$

Isles of Scilly

Melton

$-1.1$

Hounslow

$-0.5$

$-0.8$

$-0.4$

$-0.5$ 


\section{Appendix A3: Impact of Brexit Across Primary Urban Areas}

The results presented in the main body of the text, and in Appendix A2 are for Local Authorities. These have the advantage that they cover the whole of Great Britain and thus give an estimate of the impact of Brexit for all areas. However, when large number of households commute across a Local Authority boundary for work we can get better predictions of the impact of Brexit on households if we look at the impact on functional economic areas - defined, somewhat circularly, as the spatial scale at which the relevant economic markets operate. To take a more concrete example, for a household living in one of our big cities, predictions at the urban area level are more likely to capture the impact on the income of that household. In this appendix we present such results for Primary Urban Areas (PUAs), a convenient aggregation of Local Authorities that better match urban economies than stand-alone Local Authorities.

Basic summary statistics for the impact across PUAs are reported in Table A2. In line with the national and Local Authority estimates, the average PUA level effect is negative under both scenarios and more negative under hard Brexit. Comparing to Table 2, we see that the mean impact for PUAs is somewhat higher than that for Local Authorities, consistent with the suggestion in the main text that the employment concentration of urban areas mean that they are predicted to be somewhat harder hit than non-urban areas.

As with Local Authorities, these figures are essentially unchanged if we use the median instead of the mean, suggesting that there are no particularly extreme predictions that drive the average effect. The figures for the $10^{\text {th }}$ and $90^{\text {th }}$ percentile are also consistent with this interpretation.

Table A2 also reports the variance and $90^{\text {th }}$ to $10^{\text {th }}$ percentile different to summarise how much the negative effect of Brexit varies across PUAs under the two different scenarios. As with Local Authorities, the variation in PUA shocks is considerably higher under hard Brexit. This suggests that some PUAs are particularly specialised in sectors that are badly hit by hard Brexit. Having said this, the variation under the two different scenarios is lower for Primary Urban Areas $(0.17 \%$ for soft Brexit, $0.35 \%$ for hard Brexit) showing the importance of urban diversification in helping mitigate negative impacts. 
Table A2: PUA Distribution Statistics of GVA Impacts of Brexit

\begin{tabular}{lcc}
\hline & $\begin{array}{c}\text { Soft Brexit } \\
(\%)\end{array}$ & Hard Brexit \\
& & $(\%)$ \\
\hline Mean & -1.22 & -2.28 \\
$50^{\text {th }}$ Percentile (Median) & -1.21 & -2.26 \\
$10^{\text {th }}$ Percentile & -1.35 & -2.60 \\
$90^{\text {th }}$ Percentile & -1.07 & -1.98 \\
Standard Deviation & 0.17 & 0.35 \\
$90^{\text {th }}-10^{\text {th }}$ Percentile & 0.28 & 0.62 \\
Differential & & \\
\hline
\end{tabular}

Table A3 lists the top ten most and least affected PUAs under the hard Brexit scenario. The results for all PUAs are provided in Table A4. The most affected PUAs show slightly more geographical diversity in comparison to the most affected Local Authorities (which, with the exception of Aberdeen were all in the South of England). For the least affected, the underrepresentation of the South of England is somewhat more apparent than it was for Local Authorities. PUAs across Great Britain are hit harder than Local Authorities, but PUAs outside the South of England tend to be less hard hit than other PUAs. Figure A1 which maps the percentage change in GVA by PUA under both soft and hard Brexit confirms this broad geographical pattern.

Table A3: Most and Least Affected Primary Urban Areas (\% Change in Gross Value Added)

\begin{tabular}{lcc|lcc}
\hline Top 10 & $\begin{array}{l}\text { Soft Brexit } \\
(\%)\end{array}$ & $\begin{array}{l}\text { Hard } \\
\text { Brexit }\end{array}$ & \multicolumn{1}{c}{ Bottom 10 } & Soft Brexit & $\begin{array}{c}\text { Hard } \\
\text { Brexit }\end{array}$ \\
\hline \hline Aberdeen & -2.1 & -3.7 & Blackpool & $(\%)$ & $(\%)$ \\
Worthing & -1.5 & -2.8 & Swansea & -1.0 & -2.0 \\
Reading & -1.4 & -2.8 & Telford & -1.1 & -2.0 \\
Swindon & -1.5 & -2.8 & Luton & -1.1 & -2.0 \\
Slough & -1.4 & -2.8 & Mansfield & -1.1 & -2.0 \\
Edinburgh & -1.4 & -2.7 & Wakefield & -1.2 & -2.0 \\
London & -1.3 & -2.6 & Hull & -1.1 & -1.9 \\
Aldershot & -1.3 & -2.6 & Burnley & -1.0 & -1.8 \\
Leeds & -1.3 & -2.6 & Barnsley & -0.9 & -1.7 \\
Ipswich & -1.3 & -2.6 & Crawley & -0.7 & -1.1 \\
\hline
\end{tabular}


Table A4: Impact of Brexit for Primary Urban Areas

(\% Change in Gross Value Added)

\begin{tabular}{|c|c|c|}
\hline Primary Urban Area & $\begin{array}{c}\text { Soft Brexit } \\
(\%) \\
\end{array}$ & $\begin{array}{c}\text { Hard Brexit } \\
(\%) \\
\end{array}$ \\
\hline Aberdeen & -2.1 & -3.7 \\
\hline Worthing & -1.5 & -2.8 \\
\hline Reading & -1.4 & -2.8 \\
\hline Swindon & -1.5 & -2.8 \\
\hline Slough & -1.4 & -2.8 \\
\hline Edinburgh & -1.4 & -2.7 \\
\hline London & -1.3 & -2.6 \\
\hline Aldershot & -1.3 & -2.6 \\
\hline Leeds & -1.3 & -2.6 \\
\hline Ipswich & -1.3 & -2.6 \\
\hline Bristol & -1.3 & -2.6 \\
\hline Northampton & -1.3 & -2.6 \\
\hline Milton Keynes & -1.3 & -2.5 \\
\hline Cardiff & -1.3 & -2.5 \\
\hline Warrington & -1.3 & -2.5 \\
\hline Middlesbrough & -1.3 & -2.5 \\
\hline Peterborough & -1.2 & -2.5 \\
\hline Cambridge & -1.3 & -2.5 \\
\hline Brighton & -1.2 & -2.5 \\
\hline Gloucester & -1.4 & -2.5 \\
\hline Glasgow & -1.3 & -2.4 \\
\hline Exeter & -1.2 & -2.4 \\
\hline Bournemouth & -1.3 & -2.4 \\
\hline Manchester & -1.3 & -2.4 \\
\hline Nottingham & -1.2 & -2.4 \\
\hline Liverpool & -1.2 & -2.4 \\
\hline Coventry & -1.2 & -2.3 \\
\hline Norwich & -1.2 & -2.3 \\
\hline Portsmouth & -1.3 & -2.3 \\
\hline Southampton & -1.2 & -2.3 \\
\hline Southend & -1.2 & -2.3 \\
\hline York & -1.1 & -2.3 \\
\hline Newcastle & -1.2 & -2.2 \\
\hline Birkenhead & -1.2 & -2.2 \\
\hline Preston & -1.2 & -2.2 \\
\hline Chatham & -1.2 & -2.2 \\
\hline Doncaster & -1.2 & -2.2 \\
\hline Derby & -1.2 & -2.2 \\
\hline Leicester & -1.2 & -2.2 \\
\hline Dundee & -1.2 & -2.1 \\
\hline Bradford & -1.2 & -2.1 \\
\hline Plymouth & -1.1 & -2.1 \\
\hline Blackburn & -1.3 & -2.1 \\
\hline
\end{tabular}




\begin{tabular}{lll} 
Sunderland & -1.2 & -2.1 \\
Newport & -1.2 & -2.1 \\
Birmingham & -1.1 & -2.1 \\
Sheffield & -1.2 & -2.1 \\
Oxford & -1.0 & -2.0 \\
Basildon & -1.1 & -2.0 \\
Huddersfield & -1.2 & -2.0 \\
Wigan & -1.1 & -2.0 \\
Stoke & -1.1 & -2.0 \\
Blackpool & -1.0 & -2.0 \\
Swansea & -1.1 & -2.0 \\
Telford & -1.1 & -2.0 \\
Luton & -1.1 & -2.0 \\
Mansfield & -1.2 & -2.0 \\
Wakefield & -1.1 & -1.9 \\
Hull & -1.0 & -1.8 \\
Burnley & -1.1 & -1.7 \\
Barnsley & -0.9 & -1.7 \\
Crawley & -0.7 & -1.1 \\
\hline
\end{tabular}

\section{Figure A1: Map showing Percentage Decrease in Primary Urban Area GVA}
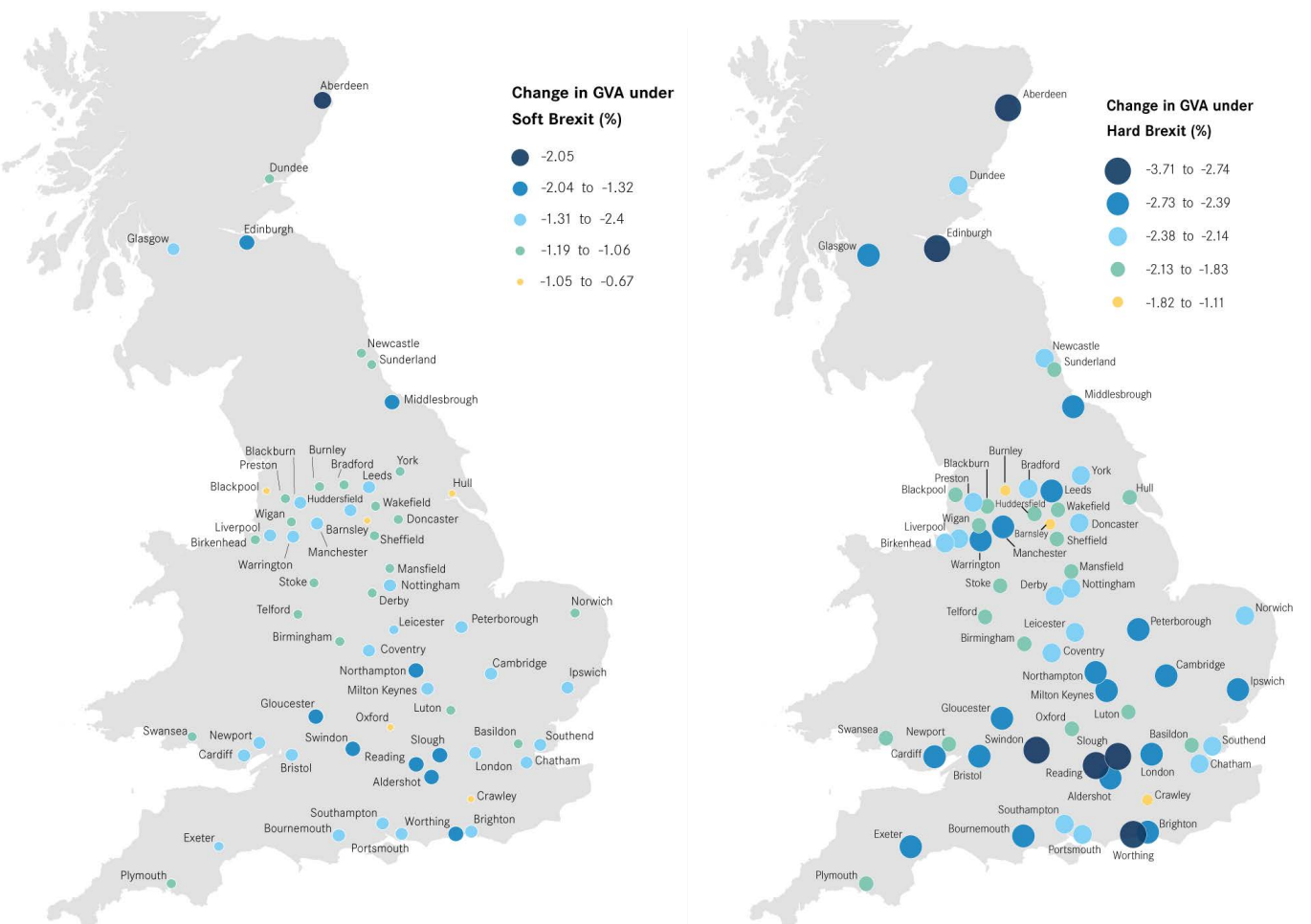

As for Local Authorities, Figure 2 shows that PUAs that are predicted to be most negatively affected by Brexit were more likely to vote remain. As with Local Authorities, the correlation is particularly striking for the predicted impacts under hard Brexit (the correlation coefficient is -0.33 for soft Brexit, -0.48 for hard Brexit). 
Figure A2: Correlation Brexit GVA Impact with Referendum Vote Share

(a) Soft Brexit

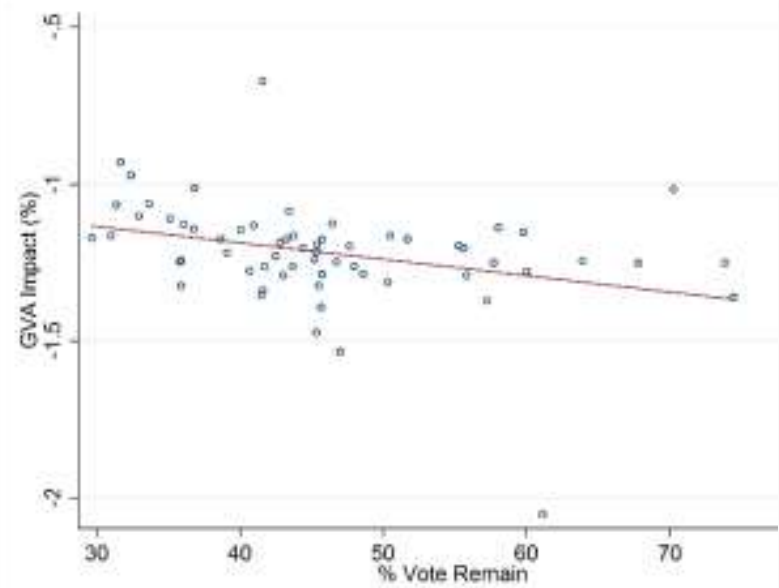

(b) Hard Brexit

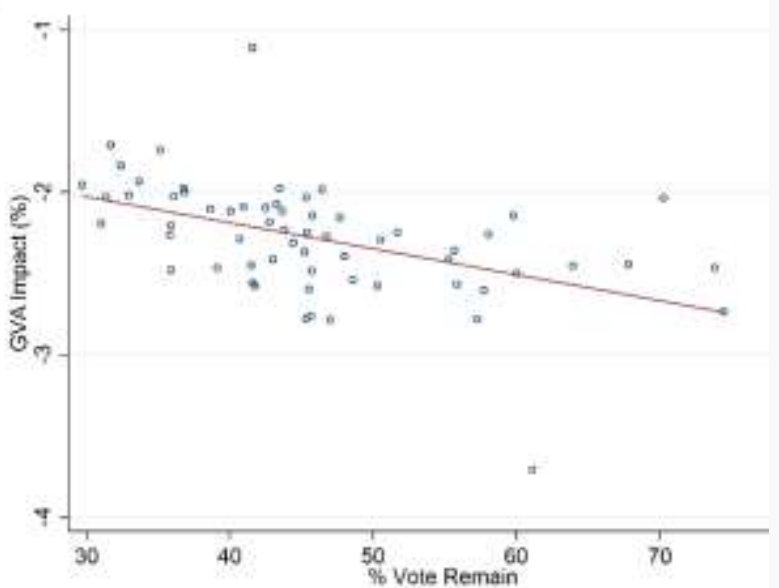

Finally, as with Local Authorities, initial differences across PUAs swamp differences in the predicted impact of Brexit as shown in Figure A3 (the correlation coefficient is -0.23 for soft Brexit, -0.37 for hard Brexit).

Figure A3: Correlation Brexit GVA Impact with Pre-Referendum Median Wage

(a) Soft Brexit

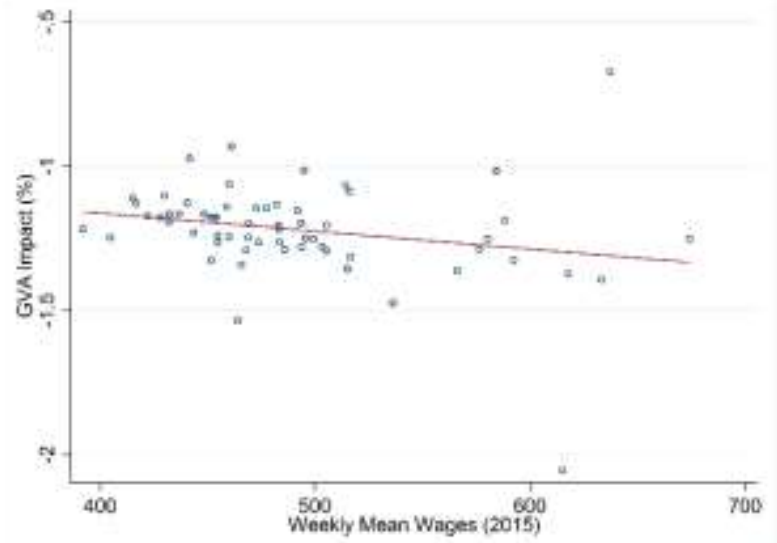

(b) Hard Brexit

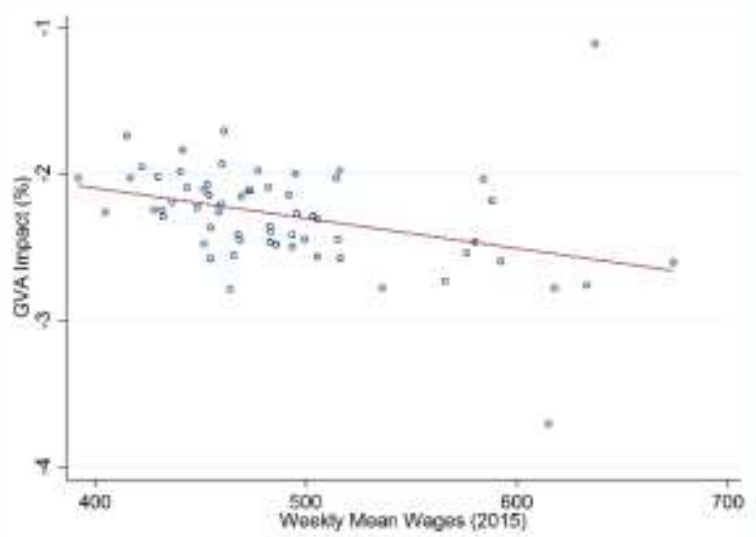

